\title{
PERANCANGAN DESAIN S-DUMPER (SMART DUMP) SEBAGAI SOLUSI DALAM PENGURANGAN SAMPAH BERSERAKAN
}

\author{
Ahmad Maulana Fikri ${ }^{1}$, Mohammad Annur Ramadhan ${ }^{2}$, Brianto Rovi Harjanto ${ }^{3}$, Tegar Palyus Fiqar ${ }^{4}$ \\ 1,2,3,4 Institut Teknologi Kalimantan, Balikpapan, Kalimantan Timur, Indonesia \\ 110171001estudent.itk.ac.id \\ ${ }^{2} 10171012$ estudent.itk.ac.id \\ ${ }^{3} 101710460$ student.itk.ac.id \\ ${ }^{4}$ tegaralecturer.itk.ac.id
}

\begin{abstract}
The inevitable consequence of human activity is rubbish. However, rubbish often is strewn outside the trash cans that can cause various diseases and cause an unpleasant odor. This can happen because the design of the trash can is wide open. Therefore, an idea emerged to design a device called $S$ DUMPER (Smart Dump) with the help of the Internet of Things and Embedded Systems. S-DUMPER aims to minimize trash scattered outside the garbage bin and help officers to transport the garbage to the final disposal site. In this research, several methods will be used, including literature study, and prototype design. The components of the S-DUMPER device are $\mathrm{HC}$ SR04 sensor, Arduino, LCD, GSM, and servo motor. Each component has its respective roles that can support the performance of the S-DUMPER tool with the concept of Embedded Systems. In addition, to maximize the delivery of information from the S-DUMPER tool, an Android-based $S$ DUMPER application design was designed. The performance of the S-DUMPER application is adapted by the Internet of Things system. The results of this study are in the form of a design of S-DUMPER tools and applications. With the $S$ DUMPER, officers can easily transport waste and speed up the performance of officers.
\end{abstract}

Keywords-Application Design, Embedded System, Internet of Things, S-DUMPER, Tool Design, Trash

Intisari-Konsekuensi yang tidak dapat dihindari dari adanya aktivitas manusia yaitu sampah. Namun, sering kali sampah-sampah berserakan di luar bak sampah yang dapat menimbulkan berbagai penyakit dan mendatangkan bau yang tidak nyaman. Hal ini dapat terjadi karena desain dari bak sampah yang terbuka lebar. Oleh karena itu, peneliti mengusulkan suatu alat yang bernama S-DUMPER (Smart Dump) dengan bantuan Internet of Things dan Embedded Systems. S-DUMPER bertujuan meminimalisir sampah yang berserakan di luar bak sampah dan membantu petugas untuk mengangkut sampah ke tempat pembuangan akhir. Pada penelitian ini, akan digunakan beberapa metode meliputi studi literatur, perancangan prototipe. Komponen dari alat S-DUMPER berupa sensor HC-SR04, Arduino, LCD, GSM dan motor servo. Setiap komponen memiliki peran masingmasing yang dapat mendukung kinerja dari alat S-DUMPER dengan konsep Embedded System. Selain itu, untuk memaksimalkan penyampaian informasi dari alat $S$ DUMPER, dirancang desain aplikasi S-DUMPER berbasis android. Kinerja aplikasi S-DUMPER diadaptasikan oleh sistem Internet of Things. Hasil dari penelitian ini berupa rancangan desain dari alat dan aplikasi S-DUMPER. Dengan adanya S-DUMPER, petugas dapat mengangkut sampah dengan mudah dan mempercepat kinerja petugas.

Kata Kunci-Desain Alat, Desain Aplikasi, Embedded System, Internet of Things, S-DUMPER, Sampah

\section{PENDAHULUAN}

Dalam upaya memenuhi kebutuhan hidup, berbagai macam aktivitas dilakukan oleh manusia. Konsekuensi dari adanya aktivitas manusia yaitu sampah. Hasil buangan yang dihasilkan dari suatu proses produksi, baik industri maupun rumah tangga disebut dengan sampah. Tentunya, kehadiran sampah tidak dapat dihindari dikarenakan sampah sebagai hasil buangan dari aktivitas domestik, komersil maupun industri. Sampah dapat berasal dari beberapa tempat, yaitu pemukiman penduduk, tempattempat umum dan perdagangan. Dikutip dari IDNTIMES [1], Direktur Jenderal Pengelolaan Sampah, Limbah dan Bahan Beracun Berbahaya (B3) mengatakan bahwa proyeksi volume sampah rumah tangga dan sejenis sampah rumah tangga di Indonesia pada 2018 mencapai 66,5 juta ton.

Pemerintah telah menyediakan tempat pembuangan sampah untuk masyarakat, dimana setiap harinya akan ada petugas yang mengangkut sampah tersebut ke pembuangan akhir. Namun, sering kali sampah-sampah berserakan di luar bak sampah. Seperti yang dilansir pada kompas.com, tumpukan sampah berserakan di bawah jalan layang Ciputat, Tangerang Selatan menebar bau tidak sedap [2]. Hal ini terjadi karena desain bak sampah yang terbuka lebar, sehingga masyarakat membuang sampah tidak pada tempatnya. Sebagai contoh hanya melempar sampah dari kendaraan, sehingga terkadang tidak tepat masuk ke dalam bak sampah. Sampah yang berserakan dapat mencemari lingkungan, menimbulkan berbagai penyakit dan mendatangkan bau yang tidak nyaman. Selain itu, petugas yang bertugas mengangkutnya pun kesulitan dalam bekerja.

Pada penelitian yang dilakukan oleh Setiawan dkk (2014), dilakukan rancang bangun alat pembuka dan penutup tong sampah otomatis berbasis mikrokontroler [3]. Penelitian ini menghasilkan alat pembuka dan penutup tong sampah secara otomatis dengan mengandalkan gerakan tubuh manusia. Jika terdapat seseorang yang mendekat, maka alat tersebut akan membuka tempat sampah secara otomatis. Penelitian serupa juga dilakukan oleh Hidayat (2017), dimana dilakukan penelitian terkait perancangan sistem kontrol Arduino pada tempat sampah menggunakan sensor [4]. Penelitian ini menghasilkan tempat sampah otomatis yang unik serta interaktif, dimana dapat mengeluarkan suara ajakan untuk membuang sampah pada tempatnya. Selain itu, alat ini juga dapat mendeteksi objek di dekatnya dan mengaktifkan 
mekanisme buka tutup tempat sampah secara otomatis. Terakhir, juga dilakukan penelitian oleh Sukarjadi (2017) yang merancang dan membuat smart trash bin berbasis Arduino uno [5]. Penelitian ini menghasilkan tempat sampah yang memiliki fitur yang sama seperti penelitian sebelumnya yaitu buka tutup secara otomatis. Selain itu, juga terdapat fitur yang dapat memberikan pemberitahuan jika sampah telah penuh melalui lampu yang ditaruh di atas tempat sampah. Setelah dilakukan analisis pada penelitian terdahulu, terdapat beberapa poin yang dapat dikembangkan yaitu fitur pemberitahuan volume sampah yang tersisa secara realtime.

Dari permasalahan yang dipaparkan sebelumnya, muncul suatu gagasan untuk merancang suatu alat yang bernama S-DUMPER (Smart Dump) dengan bantuan Internet of Things dan Embedded System. S-DUMPER bertujuan meminimalisir sampah yang berserakan di luar bak sampah dengan merubah kebiasaan masyarakat dan membantu petugas untuk mengangkut sampah ke tempat pembuangan akhir. S-DUMPER memiliki beberapa komponen yang dapat mendukung fitur untuk membuka dan menutup tempat sampah secara otomatis. Selain itu, dilengkapi aplikasi yang dapat melihat volume tempat sampah secara realtime dan dapat diakses oleh siapapun. Pada penelitian kali ini, dilakukan perancangan terkait alat dan aplikasi S-DUMPER. Sebelum dilakukan implementasi lebih lanjut terkait S-DUMPER, dirasa sangat diperlukan untuk melakukan perancangan terlebih dahulu. Diadaptasikan sesuai dengan siklus System Development Life Cycle (SDLC), dimana mempunyai empat kegiatan utama yaitu analisis kebutuhan, desain, implementasi dan pengujian [6]. Namun, dalam penelitian ini mempunyai batasan yaitu berfokus pada tahapan analisis kebutuhan sampai dengan desain sistem. Dengan adanya S-DUMPER, diharapkan petugas dapat melakukan pekerjaannya dengan efektif dan efisien. S-DUMPER juga meminimalisir masyarakat membuang sampah sembarangan, sehingga sampah tidak lagi berserakan di luar bak sampah.

\section{LANDASAN TEORI}

\section{A. Sampah}

Menurut UU-18/2008, tentang Pengelolaan Sampah, sampah dapat didefinisikan sebagai sisa kegiatan seharihari manusia dan/atau proses alam yang berbentuk padat. Terdapat sampah yang diatur dalam UU-18/2008 antara lain sampah rumah tangga, sampah sejenis sampah rumah tangga, dan sampah spesifik [7].

\section{B. Internet of Things (IoT)}

Manfaat dari konsep IoT sangatlah banyak, beberapa manfaat dari konsep IoT ini yaitu dalam pengaplikasian smart cities. Kesehatan, pendidikan, dan aktivitas-aktivitas lainnya yang sering dilakukan. Dalam pengaplikasian smart cities seperti lampu jalan yang otomatis menyala ketika akan malam dan otomatis mati kembali ketika akan pagi, update otomatis untuk penumpang bus, smart traffic light dengan kamera untuk memantau kemacetan, kamera yang dapat dipantau jarak jauh hanya dengan smartphone, dan berbagai manfaat lain. Dalam dunia kesehatan pemanfaat konsep IoT seperti perangkat yang tersambung menangkap indikator kesehatan dan memperbarui laporan medis secara real time mengirimkan peringatan kepada dokter sehingga perawatan dapat diikuti dengan benar.

Peringatan juga berguna untuk mengingatkan pasien mengkonsumsi obat yang diberikan dan peringatan juga diberikan kepada keluarga pasien sehingga pasien mendapat perhatian lebih. Dalam dunia pendidikan manfaat dari konsep IoT seperti siswa tidak perlu membawa banyak buku, hanya dengan smart device semua materi sekolah dapat disimpan. Dalam kegiatan seharihari, IoT juga sangat berguna seperti pertemuan manajemen berbasis fakta dan menggunakan data realtime untuk mengambil keputusan berdasarkan informasi. Jarak bukan menjadi masalah lagi karena dengan menggunakan smart device orang-orang dapat berkomunikasi dari jarak jauh dengan mudah [8].

\section{Embedded System}

Embedded System atau sistem terbenam adalah sebuah sistem yang terdiri dua atau lebih sub-sistem dan bersifat otonom. Embedded System berbasis mikroprosesor yang dibangun dalam pengontrolan suatu fungsi atau domain kerja. Sistem ini tidak didesain untuk diprogram oleh pengguna akhir (end user) seperti pada komputer. Kegunaan sistem ini yakni dirancang untuk melakukan tugas tertentu seperti sistem terbenam untuk tuning senar, tetapi tujuan keseluruhannya sebagai robot guitar [9].

\section{Sensor Ultrasonik (HC-SR04)}

HC-SR04 merupakan modul rentang ultrasonic, dimana dirancang untuk proyek embedded systems. fungsi pengukuran non-kontak $2 \mathrm{~cm}-400 \mathrm{~cm}$, akurasi jangkauan yang dapat mencapai $3 \mathrm{~mm}$ disediakan oleh modul HCSR04. Modul-modul tersebut meliputi pemancar ultrasonik, penerima dan sirkuit kontrol. Terdapat empat pin pada HC-SR04 meliputi 5V supply, trigger pulse input, echo pulse output, dan $0 \mathrm{~V}$ ground [10].

\section{E. Arduino}

Arduino berfungsi sebagai pembuat projek elektronik, dimana terdiri dari perangkat keras yaitu papan arduino dan perangkat lunak yaitu Arduino IDE. Arduino merupakan salah satu platform berbasis open source. Arduino sering digunakan dalam berbagai proyek, misalkan untuk membuat perangkat instrumen ilmiah yang kompleks. Pengguna dapat membangun prototype mereka sendiri secara indipenden dikarenakan platform open source yang disediakan arduino. Papan Arduino berfungsi sebagai pembaca masukan seperti cahaya pada sensor, sentuhan jari pada tombol, atau pesan dari Twitter dan pengubah masukan menjadi keluaran seperti tulisan saat menyalakan LED. Hal ini bisa dilakukan dengan cara mikrokontroler yang sebelumnya telah diperintahkan untuk melakukan beberapa proses melalui program yang dibuat di Arduino IDE [11].

\section{F. Penelitian Terdahulu}

Terdapat penelitian tempat sampah pintar (Smart trash bin) yang dilakukan di Universitas Maarif Hasyim Latif oleh Sukarjadi, Deby Tobagus Setiawan, Arifiyanto, dan 
Moch. Hatta. Penelitian ini bertujuan untuk meningkatkan kesadaran masyarakat akan pentingnya kebersihan lingkungan yang dimulai dari kepedulian diri. Terdapat beberapa alat yang digunakan pada penelitian Smart Trash Bin berbasis Arduino Uno, antara lain sensor HC-SR04, motor servo, rangkaian adaptor, buzzer dan LED. Perancangan modul yang dilakukan melalui tiga tahapan. Tahapan pertama yaitu perancangan software, dimana tahapan ini akan dimulai dari pendeskripsian kerja dari sistem Arduino Uno dan penetapan bahasa $\mathrm{C}++$ sebagai bahasa perancangan program. Setelah itu, perencanaan hardware yang dilakukan pada pembuatan rangkaian modul sensor jarak, LED dan buzzer. Tahapan terakhir yaitu pembandingan antara hardware dan software [5].

\section{METODE PENELITIAN}

Metode penelitian merupakan cara ilmiah yang bertujuan memperoleh dan mengumpulkan data-data sesuai dengan tujuan dan fungsi tertentu. Metode yang dilakukan dalam merancang S-DUMPER diadaptasikan dari metode SDLC, yaitu sebagai berikut.

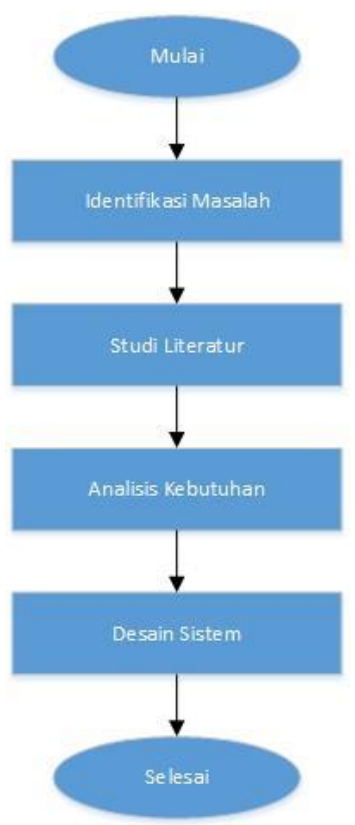

Gambar 1. Metodologi Penelitian

\section{A. Identifikasi Masalah}

Tahapan ini berhubungan dengan pengamatan terhadap keadaan obyek penelitian, dimana dalam penelitian kali ini obyek penelitian berupa tempat sampah yang ada pada masyarakat. Penulis akan mengamati keadaan yang sedang terjadi saat masyarakat membuang sampah pada bak sampah. Pada tahapan ini didapatkan bahwa terjadi permasalahan di masyarakat yaitu sampah berserakan sampai ke luar bak sampah. Hal ini dapat terjadi karena masyarakat yang tidak membuang sampah pada tempatnya maupun desain bak sampah yang terbuka lebar.

\section{B. Studi Literatur}

Pada tahapan ini, penulis mencari referensi teori-teori yang relevan dengan kasus atau permasalahan yang ditemukan. Referensi teori yang diperoleh juga akan menjadi fondasi dasar dan alat utama bagi penulis melakukan tahapan selanjutnya. Data yang didapatkan dari studi literatur berasal dari jurnal-jurnal ilmiah, buku dan laman website terkait teori dan kajian yang relevan dengan penelitian yang dilakukan. Setelah itu, referensi yang telah didapat akan dianalisis oleh penulis dan menghasilkan sebuah solusi yaitu S-DUMPER.

\section{Analisis Kebutuhan}

Pada tahapan ini, penulis menganalisis kebutuhan yang ada untuk merancang desain alat maupun aplikasi SDUMPER. Berikut merupakan proses yang terjadi pada $S$ DUMPER, dimana disajikan dalam bentuk activity diagram. S-DUMPER dengan bantuan embedded system dilengkapi dengan berbagai komponen untuk menjalankan kerjanya. Adapun komponen yang melengkapi SDUMPER sebagai berikut:

Tabel I.

Komponen Alat S-DUMPER

\begin{tabular}{|c|c|l|}
\hline No & Komponen & \multicolumn{1}{|c|}{ Fungsi } \\
\hline 1. & $\begin{array}{c}\text { Sensor HC- } \\
\text { SR04 }\end{array}$ & $\begin{array}{l}\text { Sensor untuk mendeteksi jarak } \\
\text { sampah dengan ketinggian } \\
\text { maksimum }\end{array}$ \\
\hline 2. & Arduino & $\begin{array}{l}\text { Mengatur LCD dan membaca } \\
\text { masukan dari sensor HC-SR04 }\end{array}$ \\
\hline 3. & LCD & $\begin{array}{l}\text { Menampilkan informasi dari } \\
\text { Arduino berupa "FULL", dimana } \\
\text { sampah telah terisi penuh }\end{array}$ \\
\hline 4. & GSM & $\begin{array}{l}\text { Penyedia koneksi untuk dikirim ke } \\
\text { aplikasi S-DUMPER }\end{array}$ \\
\hline 5. & Motor Servo & Menggerakkan pintu tempat sampah \\
\hline
\end{tabular}

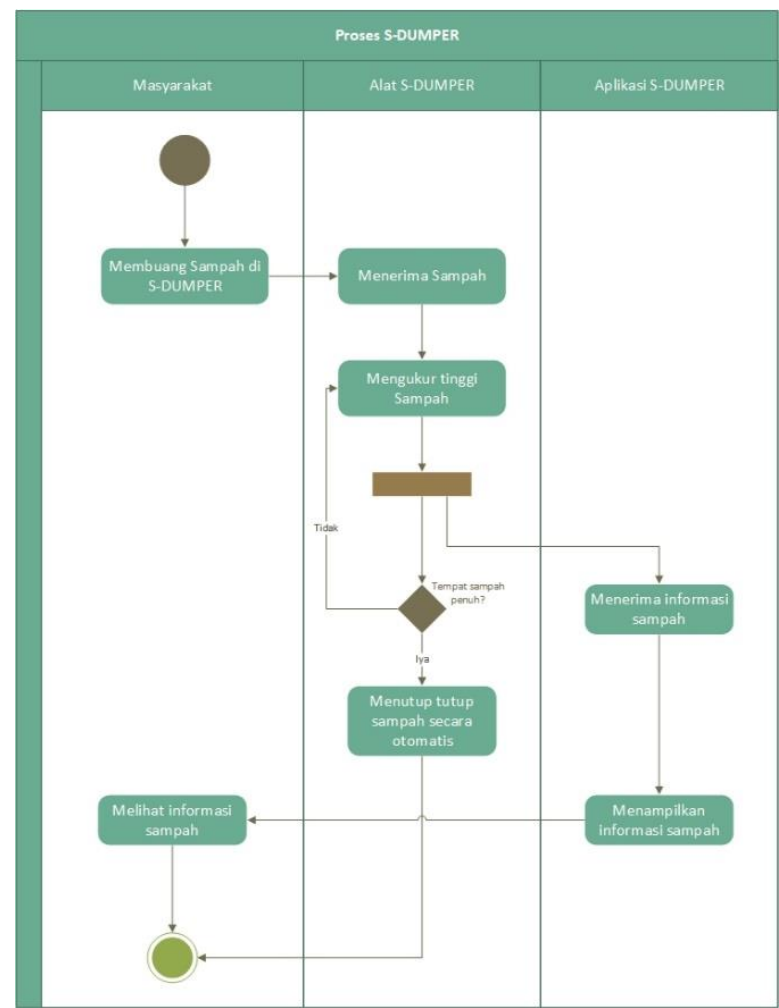

Gambar 2. Activity Diagram S-DUMPER 
S-DUMPER juga dilengkapi dengan aplikasi SDUMPER yang mengimplementasikan konsep Internet of Things (IotT). Adapun fitur yang diterapkan sebagai berikut.

Tabel II.

Fitur Aplikasi S-DUMPER

\begin{tabular}{|c|c|c|}
\hline No & Fitur & Fungsi \\
\hline 1. & $\begin{array}{l}\text { Register dan } \\
\text { Login }\end{array}$ & $\begin{array}{l}\text { Mendaftar pengguna yang } \\
\text { ingin menggunakan } \\
\text { aplikasi S-DUMPER. Jika } \\
\text { pengguna telah terdaftar } \\
\text { pada sistem, maka dapat } \\
\text { login ke aplikasi. }\end{array}$ \\
\hline 2. & $\begin{array}{c}\text { Letak } \\
\text { S-DUMPER }\end{array}$ & $\begin{array}{l}\text { Pengguna dapat } \\
\text { mengetahui letak S- } \\
\text { DUMPER yang disajikan } \\
\text { dalam bentuk maps di } \\
\text { setiap kota. }\end{array}$ \\
\hline 3. & $\begin{array}{c}\text { Kapasitas } \\
\text { S-DUMPER }\end{array}$ & $\begin{array}{l}\text { Menampilkan informasi } \\
\text { sisa ruang yang ada pada } \\
\text { S-DUMPER. Informasi } \\
\text { tersebut disajikan dengan } \\
\text { warna untuk } \\
\text { mengindikasikan } \\
\text { kapasitas yang masih } \\
\text { tersedia. Selain itu, jika } \\
\text { pengguna memilih satu } \\
\text { alat S-DUMPER, maka } \\
\text { sistem akan menyajikan } \\
\text { informasi lebih lanjut } \\
\text { terhadap persentase setiap } \\
\text { ruangnya yang terisi. }\end{array}$ \\
\hline
\end{tabular}

D. Desain Sistem

Setelah itu, penulis membuat suatu prototipe dengan desain untuk mendapatkan rancangan sistem yang akan dibuat. Dalam hal ini, penulis akan merancang $\mathrm{S}$ DUMPER dalam bentuk desain. Desain yang dirancang yaitu berupa alat dan aplikasi S-DUMPER.

\section{HASIL DAN PEMBAHASAN}

Berikut merupakan rancangan prototipe S-DUMPER yang telah dibuat, meliputi tempat sampah dan aplikasi yang telah diasumsikan oleh peneliti terkait ukuran tempat sampah.

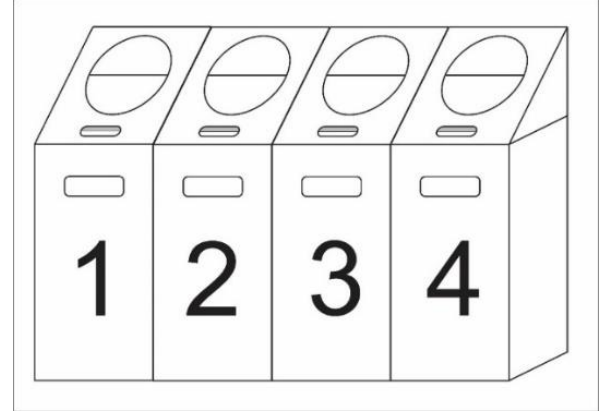

Gambar 3. Desain Alat S-DUMPER

Gambar 3 merupakan desain dari alat S-DUMPER. Alat S-DUMPER dalam satu set memiliki 4 ruang tempat sampah yang dimana setiap wadahnya memiliki wadah dalam untuk menyimpan plastik sampah yang dilengkapi sensor HC-SR04, arduino, LCD, GSM, motor servo.

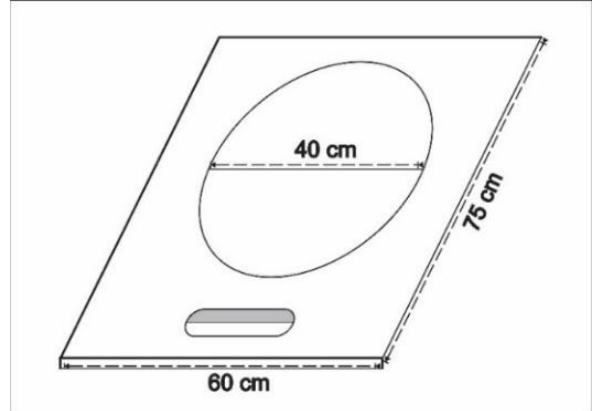

Gambar 4. Ukuran Tutup S-DUMPER

Gambar 4 merupakan desain tutup S-DUMPER. Ukuran dari tempat tutup S-DUMPER yaitu $60 \mathrm{~cm}$ dan 75 cm. Sedangkan ukuran dari tutup S-DUMPER yaitu berdiameter $40 \mathrm{~cm}$.

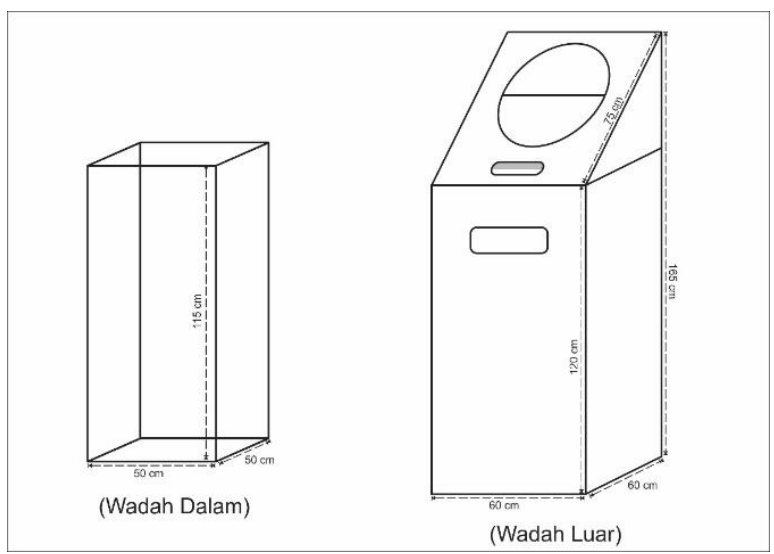

Gambar 5. Ukuran S-DUMPER

Gambar 5 merupakan desain ukuran dari wadah luar dan dalam S-DUMPER. Wadah dalam yang digunakan untuk menaruh plastik sampah berukuran $(50 \times 50 \times 115) \mathrm{cm}$. Sedangkan wadah luar terdiri dari dua yaitu wadah tempat S-DUMPER dan wadah luar, wadah tempat S-DUMPER berukuran $(60 \times 60 \times 45) \mathrm{cm}$ dan wadah luar berukuran (60x60x120) $\mathrm{cm}$.

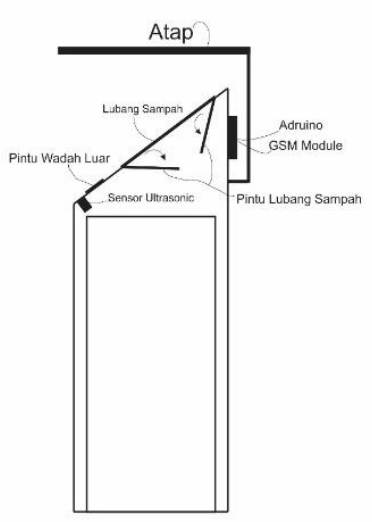

Gambar 6. Komponen S-DUMPER 
Gambar 6 merupakan desain komponen yang terdapat pada S-DUMPER. Arduino dan GSM akan ditaruh dibelakang tempat tutup S-DUMPER dimana akan dilindungi oleh atap dari cuaca yang tidak mendukung. Sensor HC-SR04 akan ditaruh didalam wadah luar yang akan menyorot langsung ke wadah dalam sehingga sensor akan mendapatkan data dari tinggi sampah yang telah diatur.

S-DUMPER dilengkapi berbagai sensor untuk memaksimalkan kinerja alat. Alat ini terbagi empat ruang dengan setiap ruangnya terdapat satu trashbag yang berukuran besar dan satu pintu. Masyarakat hanya dapat membuang sampah melalui pintu yang berada di atas bak sampah. Pintu di setiap ruangnya dihubungkan dengan sensor, dimana pintu akan tertutup otomatis jika sampah yang terisi di ruang yang tersedia telah mencapai ketinggian maksimum. Fungsi trashbag di setiap ruangnya yaitu membantu petugas untuk mengangkut sampah ke truk sampah. Ketika keempat ruang telah penuh, SDUMPER akan mengirim data ke aplikasi pemerintah yang bertujuan memberikan informasi tempat sampah yang telah penuh.

Dalam hal mendukung pemerintah, S-DUMPER dilengkapi aplikasi untuk memberikan informasi secara realtime dengan bantuan internet of things. Informasi yang dikirim dari arduino akan tersimpan ke cloud. Berikut adalah desain dari aplikasi S-DUMPER.

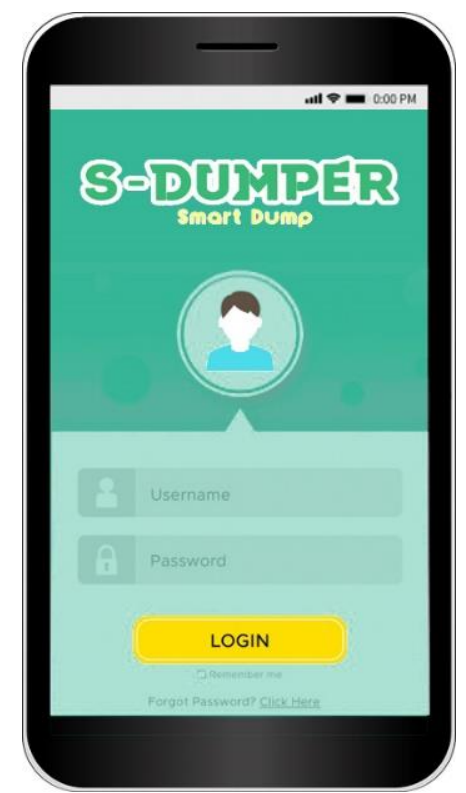

Gambar 7. Tampilan Login S-DUMPER

Gambar 7 merupakan desain tampilan login dari pengguna dan petugas sampah S-DUMPER. Pengguna memasukan username dan password sebelum masuk kedalam sistem utama S-DUMPER.

Gambar 8 merupakan desain tampilan peta letak SDUMPER. Dimana pengguna dan petugas sampah dapat melihat lokasi S-DUMPER. Terdapat 3 warna indikator yang menandakan S-DUMPER. Pertama merah yaitu menandakan S-DUMPER pada lokasi tersebut telah terisi penuh 4 ruang. Selanjutnya kuning yaitu menandakan SDUMPER pada lokasi tersebut telah terisi penuh 3 ruang.
Terakhir hijau menandakan S-DUMPER pada lokasi tersebut telah telah terisi 0-2 ruang.

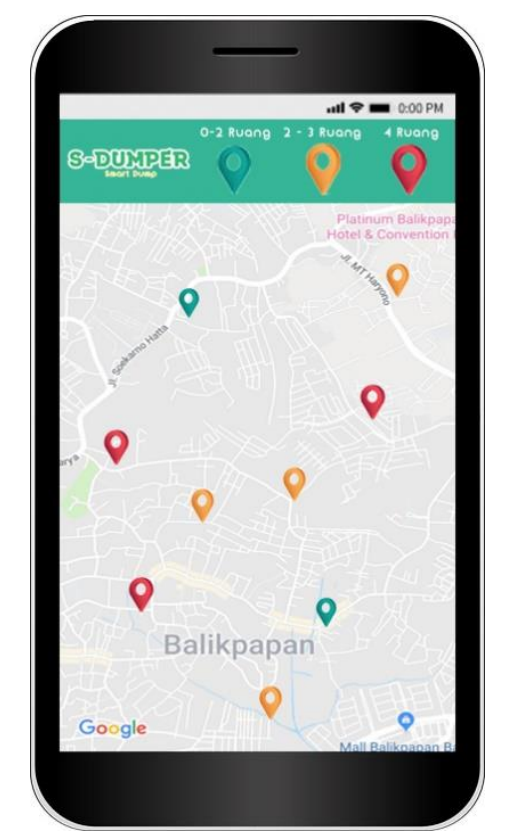

Gambar 8. Tampilan Peta Letak S-DUMPER

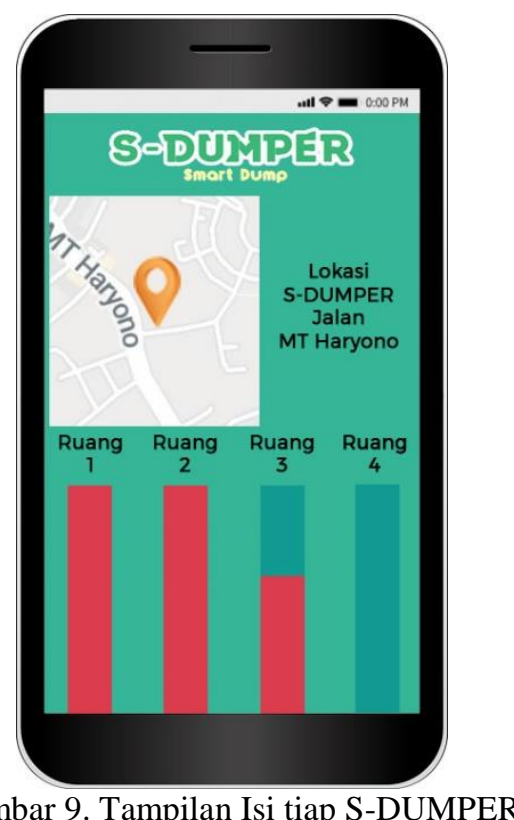

Gambar 9 merupakan tampilan dari lokasi yang telah dipilih pengguna atau petugas sampah. Setelah dipilih akan ditampilkan alamat dan sampah yang telah terisi pada ruang-ruang S-DUMPER.

\section{KESIMPULAN DAN SARAN}

Adapun simpulan yang dapat diperoleh dari yaitu dilakukan penelitian dengan empat tahapan, mulai dari identifikasi masalah, studi literatur, analisis kebutuhan dan desain sistem. Hasil yang didapatkan dari penelitian ini yaitu terciptanya desain sistem S-DUMPER berupa alat dan aplikasi. S-DUMPER dilengkapi dengan alat dan 
aplikasi yang mendukung kinerja S-DUMPER. Alat SDUMPER memiliki beberapa komponen untuk mendukung fitur buka tutup otomatis dan notifikasi volume sampah secara realtime. Aplikasi S-DUMPER memiliki fitur untuk menampilkan informasi volume sampah saat ini. Dengan adanya S-DUMPER, diharapkan petugas dapat melakukan pekerjaannya dengan efektif dan efisien. S-DUMPER juga meminimalisir masyarakat membuang sampah sembarangan, sehingga sampah tidak lagi berserakan di luar bak sampah.

Setelah itu, dirumuskan beberapa saran antara lain Penelitian ini masih dalam tahap perancangan, diharapkan dapat menjadi acuan untuk pengembangan lebih lanjut. Desain S-DUMPER dirasa masih banyak kelemahan dan ancaman. Oleh karena itu, diharapkan dapat dikembangkan agar meminimalisir kelemahan dan ancaman dari sistem yang akan dibuat.

\section{REFERENSI}

[1] I. Malia, "IDNTimes," 2018. [Online]. Available: https://www.idntimes.com/news/indonesia/indianamalia/ volume-sampah-2018-diprediksi-mencapai-665-juta-ton1. [Accessed 14 Agustus 2018].

[2] R. A. Pitoko, "Megapolitan Kompas," 2018. [Online]. Available: https://megapolitan.kompas.com/read/2018/02/22/18245 721/sampah-berserakan-dan-menebar-bau-di-bawahjalan-layang-ciputat. [Accessed 21 Januari 2019].

[3] D. Setiawan, T. Syahputra and M. Iqbal, "Rancang Bangun Alat Pembuka dan Penutup Tong Sampah Berbasis Mikrokontroler," Jurnal Teknologi dan Sistem Informasi, vol. 1, no. 1, pp. 55-62, 2014.

[4] C. R. Hidayat and F. D. Syahrani, "Perancangan Sistem Kontrol Arduino Pada Tempat Sampah Menggunakan Sensor PIR dan Sensor Ultrasonik," Jurnal VOI (Voice of Informatics), vol. 6, no. 1, 2017.

[5] Sukarjadi, D. T. Setiawan, Arifiyanto and M. Hatta, "Perancangan dan Pembuatan Smart Trash Bin Berbasis Arduino Uno di Universitas Maarif Hasyim Latif," Teknika: Engineering and Sains Journal, vol. 1, no. 2, pp. 101-110, 2017.

[6] J. F. Andry, "Pengembangan Aplikasi Backup dan Restore Secara Automatisasi Menggunakan SDLC Untuk Mencegah Bencana," Jurnal Muara Sains, Teknologi, Kedokteran dan Ilmu Kesehatan, vol. 1, no. 1, pp. 29-38, 2017.

[7] E. Damanhuri and T. Padmi, Pengelolaan Sampah, Bandung: Institut Teknologi Bandung, 2010.

[8] GSMA, Understanding the Internet of Things (IoT), London: GSMA, 2014.

[9] Sinamora, D. Renita, Rahmalia and M. Dani, Teknik Embedded-System Dalam Terapannya Untuk Membangun Sistem Deteksi Akses-Masuk Illegal, Bandung: Politeknik Telkom, 2012.

[10] M. Kaur and J. Pal, "Distance Measurement of Object by Ultrasonic Sensor HC-SR04," IJSRD - International Journal for Scientific Research \& Development, vol. 3, no. 5, pp. 503-505, 2015.
[11] N. Rinanto and S. Kautsar, Praktikum Otomasi dan Robotika, Surabaya: Politeknik Perkapalan Negeri Surabaya, 2015.

[12] Chamim and A. N. Nazilah, Penggunaan Microcontroller Sebagai Pendeteksi Posisi Dengan Menggunakan Sinyal GSM, Yogyakarta: Politeknik PPKP Yogyakarta, 2010.

[13] D. Harsono, Pemantauan Suhu Dengan Mikrokontroller ATMegaA8 Pada Jaringan Lokal, Yogyakarta: Sekolah Tinggi Teknologi Nuklir, 2009.

[14] M. Ubaidillah, Alat Ukur Kualitas Udara Menggunakan Sensor Gas MQ 135 Berbasis Mikrokontroller ATMega16A, Medan: Universitas Sumatera Utara, 2015. 